\title{
S100A4 Gene
}

National Cancer Institute

\section{Source}

National Cancer Institute. S100A4 Gene. NCI Thesaurus. Code C102437.

This gene is involved in both signaling and calcium binding. 